I must not omit to add that my best thanks are due to Dr. Bagshawe and to Mr. Travers for their kind advice and assistance, and also to the good ladies connected with a church in the neighbourhood who so tenderly and skilfully nursed the poor patient day and night until she was well out of danger.

Hastings.

\section{CASE OF MYXEDEMA IN A WOMAN AGED SEVENTY-SIX.}

BY C. W. SUCKLING, M.D. LoND., M.R.C.P., PHYSICIAN TO THE QUEEN'S HOSPITAL, BIRMINGHAM.

L. L- a woman aged seventy-six, was admitted into the workhouse infirmary on November 12th, 1884. Before I saw her the nurse of the ward told me that another case of myxodema had been admitted, she having had one, which proved fatal, for twelve months under her charge. On hearing the patient speak $I$ at once recognised the similarity of her mode of utterance and tone of voice to those of the other patient above mentioned, and it was in this way that the nurse detected the disease. No family history of importance could be "elicited, and no history of trouble, want, or excess in any way could be obtained. She had been emplnyed for years as a washerwoman, but lately had been too feeble to work. She complained only of coldness of the feet and weakness of the legs. She had had eight children, no miscarriages. She is a big, stout woman, with a heavy fatuous expression, the complexion is sallow with a circumscribed flush on each cheek. There is puffiness above and below each eyelid which does not pit on prussure. The nose is large and broad, and the alæ nasi thick. The lower lip is thick and protruded and somewhat cyanosed. There is hair on her upper lip and chin. The teeth are nearly all gone, the tongue and uvula large. The appetite bad. The skin is harsh, thick, dry, translucent, scaly, and wrinkled. She never perspires. Her limbs are large and there is a general cedema which does not pit on pressure, except in the legs and feet, where it does so slight!y. There are thick swellings resembling fat above each clavicle. The hair is very scanty. The thyroid body cannot be felt although the rings of the trachea can be distinguished down to the sternum. The heart sounds are feeble, the pulse regular, small, feeble, and infrequent, 48 per minute, and there is certainly cardiac debility. The respiration is slow (13 per minute). She complains of a sensation of coldness in her feet, also of tingling, numbness, and formication in the hands and feet. Perceptions of pain and touch are retarded; localisation perfect. The pupils are unequal; they respond to light and accommodation. The hearing is very defective. Taste and smell normal. The reflexes are normal. She is slow in her movements, and fumbles in dressing herself; her gait is slow, with short steps. There is no agoraphobia or pain in the head. The speech is slow and drawling, and exactly resembles that of the other cases I have seen. Her intelligence appears fairly good; the memory is defective. She is slow of perception, and takes a considerable time to appreciate and answer a question. The temperature is below normal, ranging from $95^{\circ}$ to $97^{\circ} \mathrm{F}$. The urine averages forty ounces daily, contains no albumen, and its specific gravity is 1010 . The percentage of urea estimated by Squibb's process is 1.15 per cent. For the last few days she has suffered from diarrhoea. She is very quiet and placid, and has had no fits or attacks of excitement.

This case is the third one of myxoedema that I have had under my care. All three have been women-two of them about the climacteric period of life. Two have proved fatal after being under observation for several months. In both of these fatal cases there were convulsions, shortly preceding death, which was by coma. In one of them delusions and attacks of temporary excitement occurred. In all the temperature was low, the urea diminished, and the heart feeble and slowly beating. In one of the fatal cases a gradual slowing of the pulse began two or three days before death, a few hours before death being 20 per minute, the patient at the time being comatose. No albumen could be detected in the urine examined shortly before death. Two of the patients were sisters. One of the patients fractured her patella; this was probably accounted for by the toneless condition of the extensor muscles of the knee, allowing the knee to give way suddenly, and the effort to recover herself fracturing the bone. I have tried jaborandi, nitro-glycerine, iron, arsenic, and baths in these cases without any appreciable benefit to the patient. The prognosis, in my experience, is of course very grave, the patient at any time being liable to a fatal coma. Dr. Oliver, in a clinical lecture on Myxoedema, called attention to a pause between inspiration and expiration as long as the sound of inspiration itself. This has not been present in the cases I have seen. West, however, ${ }^{1}$ describes alterations in the respiratory murmurs, and says that Cheyne-Stokes breathing has been observed in this disease. Many case of myxœdema have now been published, but I cannot find any case approaching in age this one.

Birmingham.

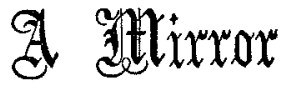

\section{H O S P T AL PRACTICE, BRITISH AND FOREIGN.}

Nulla autem est alia pro certo noscendi via, nisi quamplurimas at morborum et dissectionum historias, tum aliorum tum proprias collectas habere, et inter se comparare.-MongagnI De Sed. et Caus. Morb., lib. iv. Proœmium.

\section{ST. GEORGE'S HOSPITAL.}

A CASE OF FACIAL CARBUNCLE; DEATH; NECROPSY.

(Under the care of Mr. Hocmes.)

THE following case is a good example of the more severe variety of the disease known as facial carbuncle, death occurring as in the majority of these cases, which are happily uncommon, from pyæmia. No decisive opinion has been arrived at by the profession as to the exact relationship between this disease and true carbuncle, some considering it as the same, modified by position, others considering it to be allied to phlegmonous erysipelas. It will be observed that, in the case recorded phlebitis of the facial and other veins was noticed, preceding the more marked symptoms of pyæmia. In the diagnosis of this disease it is important to remember its resemblance in some respects to malignant pustule.

For the following notes we are indebted to Mr. H. W. Allingham, late house-surgeon:-

Bessie J-, aged twenty, single. Family history: Father died of bronchitis at a good age; other members of the family are alive and healthy. She had always had bad health, being very anæmic, and suffering from amenorrhcea. For this she had been to Eastbourne, and had only returned about a week previous to her admittance into hospital. On Dec. 23rd she complained of some pain in the left side of her upper lip, and noticed it to be very red on its inner aspect. Hot fomentations were used, but the swelling increasing a doctor was consulted, who ordered a poultice to be applied. Deriving no benefit from this treatment she was brought to the hospital.

Dec. 27th.-On admission she appeared very anæmic, the temperature being $105^{\circ}$; pulse 140 . On the left side of her face, at the angle of the mouth, involving more of the upper than the lower lip, was a large reddish-blue indurated mass, about two inches in circumference; on this were six yellow points, from which pus could be squeezed. The rest of the side of the face was swollen, being hard and brawny, with neither sense of fluctuation nor oedema; upon this were two or three small boils scattered about. This swelling extended from the eyelids, which were thickened and closed, down to the angle of the jaw, and spreading slightly down the neck. Stimulants were given and five grains of sulphate of quinine every four hours.

28th.-The lip was still of a darkish hue, and more yellow points had made their appearance, those dotted about the cheek being very pronounced. Streaks were apparent, following the course of the facial vein and its branches, which felt like cords, being evidently due to phlebitis. The eyelids were more swollen; sordes on the teeth; tongue moist, but very dirty; skin dry. The patient was slightly delirious at night and complained of intense headache. Mr. Holmes made an incision about an inch in depth along the lip at the junction of the mucous membrane and skin, but only a little venous blood (no pus) came from the wound.

1 Boston Medical and Surgical Journal, vol, ii., page 50. 